\title{
Fingerprint Pattern of Major Ethnic Groups among Students of Ibrahim Badamasi Babangida University Lapai, Nigeria
}

\author{
Mohammed Chado Isah, Alfa Muhammad Maali, Fatima Yabagi Isah, Safiya Mohammed Yunusa \\ Department of Biology, Ibrahim Badamasi Babangida University, Lapai 920211, Nigeria
}

Article history:

Submission June 2019

Revised September 2019

Accepted October 2019

*Corresponding author:

E-mail: isachado@gmail.com

\begin{abstract}
This study is aimed at identifying fingerprint pattern of major ethnic groups among the students of Ibrahim Badamasi Babangida University (IBBU) Lapai, which can be helpful in resource management for Niger State of Nigeria. The students were grouped into Nupe, Gwari, Kambari and Non-Nigerlites. Occasions for specific ethnic groups were target for data collection which exclude exclusion criteria. The types of finger print patterns considered include Ulnar Loop, Radial Loop, Plain Arch, Tented Arch and Accidental Whorl, Plain Whorl, Double Loop Whorl and Central Pocket Whorl. The respondents' fingerprints were collected using inked stamp pad, printed onto designated potions on coded paper. The data collected were represented in percentage occurrence of the fingerprint patterns for each group. Ulnar Loop was the commonest fingerprint pattern among the students of IBBU Lapai. Also common to the groups of the students are absence of Double Loop Whorl on the right ring finger, left and right little fingers as well as Tented Arch not on the right Thumb of the students. The finger print marker for the groups were absence of Double Loop Whorl on the right ring finger and absence of Tented Arch on the left Thumb of Nupe, absence of Double Loop Whorl on the left index fingers of Gwari, Tented Arch not on left and right little fingers of Kambari speaking people studying in IBBU Lapai, those of the Non-Nigerlite students of IBBU Lapai lack Tented Arch on all their fingers and Double Loop Whorl not on the right index finger.
\end{abstract}

Keywords: Fingerprint, Nupe, Gwari, Kambari, Non-Nigerlite

\section{Introduction}

The worldwide economic recess of year 2015 brought about the need for resource control and resource management by different groups of people worldwide. In Nigeria there are agitations of resource control by some groups while some other groups are concerned with resource management. This resource management is what brought about National Character system of employment in Nigeria, where federal employments are rationed among states, State employments rationed among Local Government Areas. Some States and Local Government within give bursary allowance to their student for personnel development. This make some people falsify their indigene-ship. There is similarity in phenotypic inheritance of people of common descendants [1]. This unique genetic characteristic includes but not limited to fingerprint pattern [2]. Awasthi et al. affirmed that the development of fingerprint pattern is determined by genetic and environmental factors such as nutrients, oxygen, and blood flow [3]. O'Gorman describe the use of minutia graph of fingerprints for personal authentications, this is applied in providing security for personal access to personal belongings like handsets, laptop, rooms

\section{How to cite:}

Isah MC, AM Muhammad, FI Yabagi, SY Mohammed (2020) Fingerprint Pattern of Major Ethnic Groups among Students of Ibrahim Bada-masi Babangida University Lapai, Nigeria. Journal of Tropical Life Science 10 (1): 43 - 47. doi: 

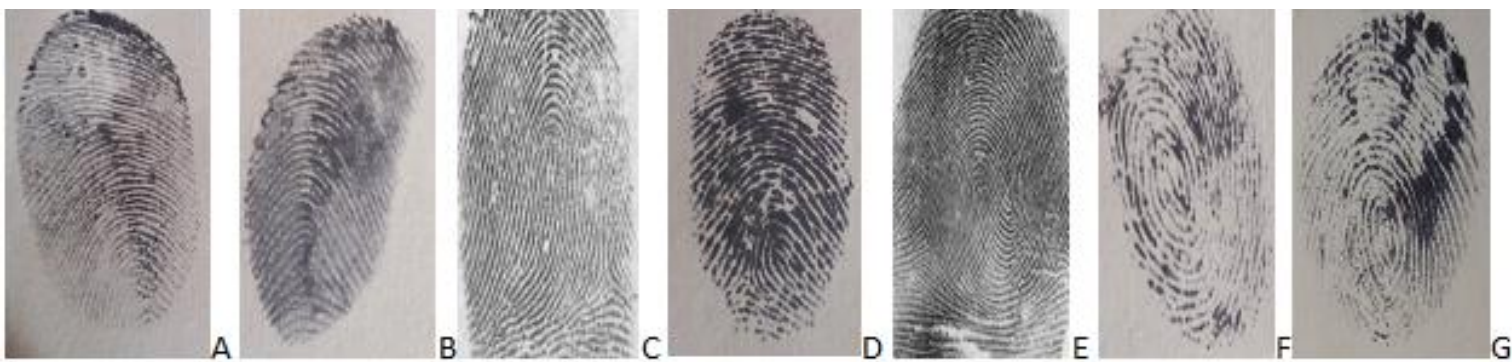

Figure 1. Finger print patterns: A) Plain Arch, B) Tented Arch, C) Ulnar Loop, D) Radial Loop E) Double Loop Whorl F) Central Pocket Whorl G) Plain Whorl

bank account etc. [4].

A study describes Arch, Loop and Whorl as the major types of fingerprint patterns and further describe Tented Arch, Plain Arch, Radial Loop, Ulnar Loop and four types of whorl including plain whorl, central pocket loop whorl, double loop whorl and accidental whorl [5]. Henry (2004) added composite to the three major type of fingerprint pattern and described three types of composites types [6]. Kingston and Kirk describe 12point rules used in fingerprint identification [7], while Robert and Clarence describe expertise in fingerprint recognition [8]. Ramotowski Identified many chemicals used in recovering the latent print and classified most to be toxic but did not blame the use since they were discovered by accident [9]. Jain et al. (2010) observed that the automatic fingerprint identification systems translate the fingerprint images to Minutiae which would not be useful for this study [10]. Beslay and Galbally (2015) assess the accuracy of automatic fingerprint identification systems and enumerate its problems [11]. Nikmah and Fatchiyah noted approximately 65 - 70\% ulnar loop pattern among Chinese ethnic group and similarity value of $75 \%$ between the parental and first filial second child of Chinese family where inherited patterns are ulnar loops, tented arch and plain whorl. The used exclusion criteria method employed by Nikmah and Fatchiyah (2017) that allows some level of biasness on the side of the research and the nuclear family considered would not give enough representation of a good homogeneous population [12]. This research aimed to find the peculiar finger print patterns of the different group of students in IBBU Lapai using the group's social function for data collection.

\section{Material and Methods}

This research was carried out among the stu- dents of Ibrahim Badamasi Babangida University (IBBU) Lapai, Nigeria. Samples were collected from November 2017 to March 2018 and analysed in the Department of Biological Sciences, IBBU Lapai, Nigeria. Fingerprints were collected randomly among students of the university, most especially during their ethnic gatherings which exclude exclusion criteria of $[12,13]$.

\section{Fingerprint pattern collection and identification}

The method used by Nikmah and Fatchiyah (2017) was adopted for fingerprint collection as described below; the respondents' fingers were clean with alcohol and dried with tissue, the fingerprint pattern is taken by pressing each finger using inked stamp pad and printed onto designated potions on coded the white paper with serial numbers for each finger [12], printing the fingerprint pattern was done by pressing the inked finger on the potion provided [14]. Finger print patterns were identified on the paper (Figure 1) and the results were tabulated using Microsoft Excel 2010, by the ethnic groups, and same was used to compare by percentile of occurrence for each finger within an ethnic group in the institution. These ethnic group were labelled zone A for those in Senatorial District Zone A, which include majorly Nupe speaking people, Zone B are those in Senatorial District Zone B which include Gwari speaking people, Zone $C$ are those from Senatorial District Zone $\mathrm{C}$ including the Kambari speaking people while Zone $\mathrm{D}$ include people from other states in Nigeria other than those from Niger state.

\section{Results and Discussion}

The record of the fingerprint pattern among students of Ibrahim Badamasi Babangida University (IBBU) Lapai expressed in percentage according to the finger and the type of pattern expressed 
Table 1. Occurrence of fingerprint patterns among Nupe people of Niger State studying in IBBU Lapai expressed in percentage

\begin{tabular}{|c|c|c|c|c|c|c|c|c|c|c|}
\hline \multirow{2}{*}{ Pattern } & \multicolumn{5}{|c|}{ Left hand finger (\%) } & \multicolumn{5}{|c|}{ Right hand finger (\%) } \\
\hline & $\mathrm{T}$ & I & $\mathrm{M}$ & $\mathrm{R}$ & L & $\mathrm{T}$ & I & M & $\mathrm{R}$ & $\mathrm{L}$ \\
\hline UL & 40 & 53 & 59 & 67 & 84 & 45 & 51 & 70 & 67 & 80 \\
\hline PA & 28 & 15 & 13 & 7 & 6 & 21 & 16 & 7 & 4 & 7 \\
\hline PW & 13 & 15 & 19 & 23 & 5 & 15 & 23 & 13 & 23 & 7 \\
\hline DLW & 15 & 4 & 3 & 0 & 0 & 12 & 3 & 2 & 0 & 0 \\
\hline RL & 4 & 12 & 3 & 2 & 4 & 4 & 5 & 4 & 4 & 4 \\
\hline CPLW & 0 & 0 & 0 & 0 & 0 & 3 & 0 & 1 & 0 & 0 \\
\hline $\mathrm{TA}$ & 0 & 1 & 3 & 1 & 1 & 0 & 1 & 2 & 2 & 1 \\
\hline AW & 0 & 0 & 0 & 0 & 0 & 0 & 0 & 0 & 0 & 0 \\
\hline Total & 100 & 100 & 100 & 100 & 100 & 100 & 100 & 100 & 100 & 100 \\
\hline
\end{tabular}

Table 2. Occurrence of fingerprint patterns among Gwari people of Niger State studying in IBBU Lapai expressed in percentage

\begin{tabular}{lcccccccccc}
\hline \multirow{2}{*}{ Pattern } & \multicolumn{4}{c}{ Left hand finger (\%) } & \multicolumn{7}{c}{ Right hand finger (\%) } \\
\cline { 2 - 11 } & T & I & M & R & L & T & I & M & R & L \\
\hline UL & 45 & 40 & 54 & 59 & 73 & 49 & 47 & 60 & 61 & 75 \\
PA & 22 & 17 & 16 & 7 & 6 & 13 & 11 & 9 & 5 & 7 \\
PW & 16 & 14 & 13 & 16 & 10 & 16 & 17 & 12 & 16 & 5 \\
DLW & 8 & 0 & 1 & 0 & 0 & 8 & 1 & 4 & 0 & 0 \\
RL & 4 & 11 & 4 & 5 & 6 & 6 & 12 & 5 & 6 & 8 \\
CPLW & 5 & 12 & 8 & 12 & 4 & 8 & 8 & 7 & 10 & 4 \\
TA & 0 & 6 & 4 & 1 & 1 & 0 & 4 & 3 & 2 & 1 \\
AW & 0 & 0 & 0 & 0 & 0 & 0 & 0 & 0 & 0 & 0 \\
Total & 100 & 100 & 100 & 100 & 100 & 100 & 100 & 100 & 100 & 100 \\
\hline
\end{tabular}

Note:

Key: $\mathrm{T}=$ Thumb, $\mathrm{I}=\mathrm{Index}, \mathrm{M}=$ Middle, $\mathrm{R}=$ Ring, $\mathrm{L}=$ Little, $\mathrm{UL}=$ Ulnar Loop, $\mathrm{RL}=$ Radial Loop, $\mathrm{PA}=$ Plain Arch, TA= Tented Arch, AW = Accidental Whorl, PW= Plain Whorl, DLW= Double Loop Whorl, CPLW= Central Pocket Whorl. Pattern of highest occurrence are in Red colour

in percentage are presented in Table $1-4$ according to the major ethnic groups. Accidental Whorl (AW) do not appear among persons of Zone A (Nupe people), Zone B (Gwari people), Zone C (Kambari people) and Zone D (Non-Nigerlites) as expressed in Table 1, 2, 3, and 4 respectively, in the same trend, accidental whorl was also absent in the record of Nikmah and Fatchiyah [12].

The fingerprint pattern commonest among the ten fingers of the four groups is the Ulnar Loop (UL) having high percentages of occurrence (84\%) in the little finger of left hand among Nupe people, Table 1 . This result is similar to the findings of Nikmah and Fatchiyah (2017) where Ulnar Loop was common on the little finger, the left thumb, and the right middle finger among Chinese ethnic families, they noticed Whorl appearing in all the fingers of Javanese ethnic family and mixed Chinese-Javanese family [12].

Tented Arch (TA) were completely absent on the fingers of Non-Nigerlites studying in IBBU Lapai. TA does not occur on the right Thumb of Nupe, Gwari, and Kambari students of IBBU Lapai, also Double Loop Whorl (DLW) does not occur on the right ring finger, left and right little fingers of Nupe, Gwari, and Kambari Non-Nigerlites.

Nupe and Gwari has no TA on their left Thumb, DLW were also not on the left index fingers of Gwari and Non-Nigerlites, DLW were equally not on the left and right middle fingers of 
Table 3. Occurrence of fingerprint patterns among Kambari people studying in IBBU Lapai expressed in percentage

\begin{tabular}{lcccccccccc}
\hline \multirow{2}{*}{ Pattern } & \multicolumn{4}{c}{ Left hand finger (\%) } & \multicolumn{7}{c}{ Right hand finger (\%) } \\
\cline { 2 - 11 } & $\mathrm{T}$ & $\mathrm{I}$ & $\mathrm{M}$ & $\mathrm{R}$ & $\mathrm{L}$ & $\mathrm{T}$ & $\mathrm{I}$ & $\mathrm{M}$ & $\mathrm{R}$ & $\mathrm{L}$ \\
\hline UL & 46 & 46 & 49 & 50 & 76 & 39 & 38 & 54 & 43 & 67 \\
PA & 14 & 11 & 10 & 7 & 4 & 13 & 10 & 11 & 4 & 9 \\
PW & 22 & 27 & 20 & 28 & 13 & 27 & 22 & 19 & 32 & 13 \\
DLW & 10 & 1 & 0 & 2 & 0 & 13 & 1 & 0 & 0 & 0 \\
RL & 3 & 6 & 6 & 5 & 6 & 3 & 13 & 6 & 6 & 6 \\
CPLW & 3 & 7 & 10 & 7 & 1 & 6 & 13 & 6 & 12 & 6 \\
TA & 1 & 1 & 4 & 2 & 0 & 0 & 3 & 4 & 3 & 0 \\
AW & 0 & 0 & 0 & 0 & 0 & 0 & 0 & 0 & 0 & 0 \\
Total & 100 & 100 & 100 & 100 & 100 & 100 & 100 & 100 & 100 & 100 \\
\hline
\end{tabular}

Table 4. Occurrence of fingerprint patterns among Non-Nigerlites studying in IBBU Lapai expressed in percentage

\begin{tabular}{|c|c|c|c|c|c|c|c|c|c|c|}
\hline \multirow{2}{*}{ Pattern } & \multicolumn{5}{|c|}{ Left hand finger (\%) } & \multicolumn{5}{|c|}{ Right hand finger (\%) } \\
\hline & $\mathrm{T}$ & I & $\mathrm{M}$ & $\mathrm{R}$ & L & $\mathrm{T}$ & I & $\mathrm{M}$ & $\mathrm{R}$ & $\mathrm{L}$ \\
\hline UL & 12 & 38 & 46 & 59 & 67 & 31 & 48 & 73 & 52 & 69 \\
\hline PA & 31 & 15 & 4 & 11 & 11 & 19 & 7 & 4 & 4 & 12 \\
\hline PW & 27 & 8 & 23 & 22 & 11 & 23 & 7 & 12 & 16 & 8 \\
\hline DLW & 8 & 0 & 0 & 0 & 0 & 8 & 0 & 0 & 0 & 0 \\
\hline RL & 8 & 19 & 12 & 4 & 7 & 4 & 22 & 8 & 16 & 8 \\
\hline CPLW & 15 & 19 & 15 & 4 & 4 & 15 & 15 & 4 & 12 & 4 \\
\hline $\mathrm{TA}$ & 0 & 0 & 0 & 0 & 0 & 0 & 0 & 0 & 0 & 0 \\
\hline AW & 0 & 0 & 0 & 0 & 0 & 0 & 0 & 0 & 0 & 0 \\
\hline Total & 100 & 100 & 100 & 100 & 100 & 100 & 100 & 100 & 100 & 100 \\
\hline
\end{tabular}

Note:

Key: $\mathrm{T}=$ Thumb, $\mathrm{I}=\mathrm{Index}, \mathrm{M}=$ Middle, $\mathrm{R}=$ Ring, $\mathrm{L}=$ Little, $\mathrm{UL}=$ Ulnar Loop, $\mathrm{RL}=$ Radial Loop, $\mathrm{PA}=$ Plain Arch, TA= Tented Arch, AW = Accidental Whorl, PW= Plain Whorl, DLW= Double Loop Whorl, CPLW= Central Pocket Whorl. Pattern of highest occurrence are in Red colour

Kambari and Non-Nigerlites and they were also not on the right index finger of the Non-Nigerlites. Iza et al. (2014) found double whorl loop as the dominant fingerprint patter on both thumbs of Arabian ethnic family and Plain Whorl on the right thumb and left index finger of Madurese ethnic family [14].

Though not commonest, Palin Arch, Plain Whorl, Central pocket Loop Whorl and Radial Loop occur on all the fingers of the other groups. The TA were not on left and right little fingers of both Kambari students of IBBU Lapai, and TA were also not on the left and right Little, Middle and Ring fingers of Non-Nigerlites studying in IBBU Lapai.

\section{Conclusion}

The Ulnar Loop is the commonest fingerprint pattern among the ten fingers of Nupe, Gwari, Kambari and Non-Nigerlites studying in IBBU Lapai. The Double Loop Whorl does not occur on the right ring finger, left and right little fingers as well as Tented Arch also not on the right Thumb of Nupe, Gwari, Kambari and Non-Nigerlites students of IBBU Lapai. The Double Loop Whorl does not occur on the right ring finger, and left and right little fingers as well as Tented Arch also not on the right Thumb of Nupe, Gwari, Kambari and Non-Nigerlites students of IBBU Lapai. The absence of Double Loop Whorl on the right ring finger and absence of Tented Arch on the left Thumb 
of Nupe, Gwari, and the Non-Nigerlites wklere their prominent fingerprint marker. The absence of Double Loop Whorl on the left index fingers is there fingerprint marker of Gwari students of IBBU Lapai. Absent on the left and right middle fingers of Double Loop Whorl is the fingerprint marker of Kambari students of IBBU Lapai. These genetic inherited characters can be used to identify the respective groups in the Ibrahim Badamasi Babangida University, Lapai campus, while fingerprint marker specific to the Non-Nigerlites students of IBBU Lapai is the absence of Tented Arch on all their fingers.

\section{Acknowledgment}

The authors of this work appreciate all the respondents who cooperated during the sampling, Nupe Students Association of Nigeria, Gwari Students Association of Nigeria and Kambari Students Association of Nigeria all of IBB University Lapai Branch who assisted during sample collection and Shehu Mohammed Ahmed for assistance during data collection.

\section{References}

1. Relethford JH (2009) Race and global pattern of phenotypic variation. American Journal of physical Anthropology 139 (1): 16 - 22. doi: 10.1002/ajpa.20900.

2. Templeton AR (2013) Biological races of human. Studies in History and Philosophy of Biomedical Science (44) 3: 262 271. doi: 10.1016/shpsc.2013.04.010.

3. Awasthi V, Awasthi V, Tiwari KK (2012) Fingerprint analysis using termination and bifurcation minutiae. International Journal of Emerging Technology and Advanced Engineering 2 (2): $124-130$.
4. O'Gorman L (1998) An Overview of fingerprint verification technologies. Elsevier Information Security Technical Report 3 (1): $21-32$.

5. Wang L, Alexander CA (2014). Fingerprint Patterns and the Analysis of Gender Differences in the Patterns Based on the U Test. International Transaction of Electrical and Computer Engineers System. 2(3): 88-92. doi: 10.12691/iteces-2-3-2.

6. Henry E R (2004) Classification and use of finger print. Indian Civil Service (CSI). http://galton.org, Accessed date: May 2019.

7. Kingston CR, Kirk PL (1965) Historical development and evaluation of " 12 point rule” in fingerprint identification. International Criminal Police Review 186: 62 - 69.

8. Robert JH, Clarence EP (2001) The Expert fingerprint witness. In: Henry CL, Gaensslen RE Eds. Advances in fingerprint technology. Washington, D. C. , CRC Press. Pp498-426

9. Ramotowski R (2013) Evolution of Latent Print Development Techniques. International Association for Identification Providence, RI. U.S. Department of Homeland Security. Pp 36.

10. Jain A K, Feng J and Nandakumar K (2010) Fingerprint matching. IEEE Computer Society 43 (2): 36 - 44.

11. Beslay L, Galbally J (2015) Fingerprint identification technology for its implementation in the Schengen Information System II (SIS-II). JRC Science Hub, European Union 100pp https://ec.europa.eu/jrc, Accessed date: May 2019.

12. Nikmah I, Fatchiyah (2017) Identification of fingerprints pattern in mixed family of Chinese-Javanese Ethnic. Journal of Tropical life Science 7 (3): 263-267 doi:1011594/jtls.07.03.12.

13. Notoatmodjo S (2010) Health research methodology. Rineka CiptA, Jakarta.

14. Iza N, Prawestiningtyas E, Fatchiyah F (2014) Forensic profiling of Javanese and Madurese families in Malang and Madura, East Java Indonesia. Cukurova Medical Journal 39 (1): 26 - 38. doi: 10.17826/cutf.10337. 
This page is intentionally left blank. 